\title{
HUBUNGAN KEMAMPUAN KOGNITIF DENGAN SIKAP SISWA PADA MATERI SISTEM PEREDARAN DARAH MANUSIA DI KELAS VIII SMP NEGERI 7 BINJAI
}

\author{
Rifkah Nafthali Br. Tarigan $^{1 *}$, Tri Harsono ${ }^{2}$, Yusriati ${ }^{3}$ \\ ${ }^{1,2}$ Program Studi Pendidikan Biologi, FMIPA, Universitas Negeri Medan, Medan JI. Willem Iskandar Psr. V Medan Estate, \\ Medan, Indonesia, 20221 \\ ${ }^{3}$ SMP Negeri 7 Binjai, Jalan Sultan Hasanuddin No.10, 20714 \\ *E-mail : rifkahnafthali@gmail.com
}

\begin{abstract}
ABSTRAK
Penelitian ini bertujuan untuk mengetahui hubungan antara kemampuan kognitif dengan sikap siswa kelas VIII SMP Negeri 7 Binjai Tahun Pembelajaran 2016/2017. Jenis penelitian yang digunakan dalam penelitian ini adalah penelitian korelasional, Populasi dalam penelitian ini adalah seluruh siswa kelas VIII SMP Negeri 7 Binjai yang terdiri dari delapan kelas. Sampel penelitian ini diambil dua kelas yaitu kelas VIII ${ }_{1}$ dan VIII yang berjumlah 70 orang dengan cara random sampling. Pengumpulan data yang digunakan adalah dengan menggunakan tes kemampuan kognitif dengan 4 pilihan sebanyak 25 butir soal dan angket dengan 4 pilihan sebanyak 40 butir. Hubungan antara kemampuan kognitif dengan sikap siswa diperoleh rata - rata 69,65 dan Standar Deviasi (SD) sebesar 13,45, sedangkan rata - rata hasil sikap siswa sebesar 82,52 dan Standar Deviasi (SD) sebesar 6,84. Hasil perhitungan untuk mengetahui persamaan regresi $Y$ atas $X$ diperoleh persamaan $Y=$ $73,31+0,12 X$, hal ini menunjukkan semakin tinggi kemampuan kognitif siswa maka sikap siswa juga akan semakin baik. Dengan menggunakan hasil pengujian koefisien korelasi dengan korelasi product moment diperoleh harga $r_{\text {hitung }}$ sebesar 0,2598 yang berarti terdapat hubungan yang linier antara kemampuan kognitif (X) dengan sikap siswa (Y). Berdasarkan uji koefisien deteriminasi didapatkan konstribusi sebesar $7 \%$ sedangkan sisanya berasal dari faktor lain. Pada pengujian Hipotesis dengan Uji Keberartian (uji t) diperoleh $t_{\text {hitung }}>t_{\text {tabel }}(2,434>1,974)$ pada taraf signifikan $\alpha=0,05$. Dengan demikian maka hipotesis (Ho) dalam penelitian ini ditolak dan hipotesis $(\mathrm{Ha})$ diterima yang menyatakan ada hubungan yang signifikan.
\end{abstract}

Kata Kunci: Kemampuan Kognitif, Sikap, Sistem Peredaran Darah Manusia

ABSTRACT

This study aims to determine the relationship between cognitive ability with the attitude of students of class VIII SMP N 7 Binjai Year Learning 2016/2017. The type of research used in this study is correlational research, the population in this study is all students of class VIII SMP Negeri 7 Binjai consisting of eight classes. The sample of this research is taken two classes that is class $\mathrm{VIII}_{1}$ and $\mathrm{VIII}_{2}$ which amounted to 70 people by random sampling, Data collection used was to use conitive ability test with 4 choiches of 25 items and questionnaires with 4 choiches of 40 items. The relationship between cognitive ability and student attitudes obtained an average of 69,65 and Standard Deviation (SD) of 13,45, while the average student attitude outcome was 82,52 and Deviation Standard (SD) of 6,84. The calculation results to find the regression equation $Y$ over $X$ obtained the equation $Y=73,31+0,12 X$, this shows the higher the cognitive abilities of students then the student's attitude will also be better. By using the results of correlation coefficient test with product moment correlation, the value of $r_{\text {calculate }}$ equal to 0,2598 which means there is a linier correlation between cognitive ability $(\mathrm{X})$ with student attitude $(\mathrm{Y})$. Based on the coefficient of determination test obtained contribution of $7 \%$ while the rest comes from other factors. In testing hypothesis with significance test ( $t$ test) obtained $t_{\text {arithmetic }}>t_{\text {table }}(2,434>1.974)$ at level significant $\alpha=0,05$. Thus the hypothesis (Ho) in this study is rejected and hypothesis $(\mathrm{Ha})$ accepted that states there is a significant.

Keyword: Cognitive Ability, Attitude, Human Circulatory System

\section{PENDAHULUAN}

Belajar dan mengajar merupakan suatu proses yang mengandung tiga unsur dan dapat dibedakan, yakni tujuan pengajaran (instruksional), pengalamaan (proses) belajar-mengajar, dan hasil belajar (Sudjana, 2009). Proses belajar dapat diartikan berlangsungnya aktivitas masuknya informasi melalui panca indra yang menghasilkan pembaharuan pada kognitif dan atau pada perilaku. Proses pembelajaran diartikan pengalaman interaksi antara individu dengan pendidik dan memberi dampak terhadap perolehan sesuatu yang baru melalui alat indra pada kognitif dan perilaku. Tujuan akhir dari pendidikan adalah terbentuknya karakter (The End of Education is Character), yaitu mengetahui yang 
benar dan bertindak mulia. Dengan demikian pembelajaran yang efektif adalah pembelajaran yang dapat membangun karakter. Pendidikan pada hakikatnya adalah pemulaan pengaruh terhadap peserta didik, semua peserta didik seyogyanya mendapat perhatian yang sama dalam pendidikannya, mendapatkan pendidikan yang standar dari pendidiknya (Milfayetty, 2015).

Pendidikan diharapkan dapat meningkatkan kualitas kehidupan diberbagai sektor, maka selalu dilakukan usaha perbaikan dalam proses pendidikan yang diharapkan dapat menciptakan kualitas kehidupan yang lebih baik. Penentuan perbaikan program pendidikan tersebut harus dimulai dengan melakukan penilaian terhadap pendidikan yang telah berjalan saat ini (Mira, dkk. 2016).

Hadirnya kurikulum 2013 membuka peluang baru untuk merealisasi keberhasilan pembentukan karakter. Pembelajaran pada kurikulum ini dijabarkan melalui empat kompetensi inti. Kompetensi inti pertama untuk menanamkan sikap spiritual, sedangkan kompetensi inti kedua untuk menanamkan sikap sosial. Kedua kompetensi inti ini telah jelas akan menghasilkan terbentuknya karakter siswa. Implementasi kurikulum 2013 di Indonesia akan menjawab berhasil atau tidakkah pembentukan karakter bagi siswa (Purwanto, 2016).

Farida (2013) dalam Purwanto (2016) berdasarkan hasil penelitiannya penelitiannya menyatakan bahwa sikap kreatif siswa terbagi dalam tingkatan tinggi, sedang, maupun rendah. Siswa yang yang memiliki sikap kreatif tinggi sudah diidentikkan dengan prestasi yang tinggi pula. Menurut Damayanti (2014) dalam Purwanto (2016) pendidikan karakter adalah suatu usaha yang direncanakan secara bersama bertujuan menciptakan generasi penerus yang memiliki dasar-dasar pribadi yang baik, baik dalam pengetahuan (cognitif), perasaan (feeling), dan tindakan (action). Senada dengan pendapat Zubaedi (dalam Kurniawan, 2013) pendidikan karakter adalah pendidikan budi pekerti plus, yang intinya merupakan program pengajaran yang bertujuan mengembangkan watak dan tabiat peserta didik dengan cara menghayati nilai-nilai dan keyakinan masyarakat sebagai kekuatan moral dalam hidupnya melaui kejujuran, dapat dipercaya, disiplin, dan kerja sama yang menekankan pada afektif, (perasaan/sikap), tanpa meninggalkan ranah kognitif (berfikir rasional), dan ranah skill (keterampilan, terampil mengolah data, mengemukakan pendapat, dan kerja sama).
Berdasarkan observasi yang telah dilakukan pada tanggal 19 Desember 2016, penulis mengetahui bahwa guru Biologi kelas VIII SMP Negeri 7 Binjai mengharapkan $80 \%$ siswanya memiliki pengetahuan yang tinggi dan sikap yang baik. Pada kenyataannya harapan tersebut belum tercapai jika dilihat dari evaluasi kognitif Biologi pada materi sistem peredaran darah manusia. Ditinjau dari satu kelas yang berjumlah 37 orang, hanya 17 orang siswa yang memenuhi standar minimal kompetensi. Sehingga dapat ditafsirkan hanya $45 \%$ siswa yang memenuhi standar minimal kompetensi yang ditunjukkan dengan nilai di atas standar minimal kompetensi yang ditetapkan guru Biologi untuk mata pelajaran Biologi yaitu 75.

Tujuan penelitian ini adalah untuk memperoleh informasi tentang hubungan antara kemampuan kognitif dan sikap siswa terhadap materi sistem peredaran darah manusia di kelas VIII SMP Negeri 7 Binjai Tahun Pembelajarn 2016/2017.

\section{METODE PENELITIAN}

Penelitian ini dilaksanakan di SMP Negeri 7 Binjai di kelas VIII dan pelaksanaannya pada semester II Tahun pembelajaran 2016/2017 yang beralamat di Jalan Sultan Hasanuddin No. 10 Binjai Kota. Penelitian ini dilaksanakan pada bulan Januari-Mei 2017 • Populasi pada penelitian ini adalah seluruh siswa kelas VIII SMP Negeri 7 Binjai Tahun Pembelajaran 2016/2017 yang terdiri dari 8 kelas. Sampel pada penelitian dipilih dengan menggunakan teknik penarikan sampel kelas secara acak (random sampling) dimana setiap kelas memiliki kesempatan yang sama untuk menjadi sampel penelitian, karena tahap penyeleksian untuk masuk ke kelas tersebut sama.

Tes yang diberikan bertujuan untuk mengukur kemampuan kognitif siswa dalam mempelajari materi sistem peredaran darah manusia. Tes disusun berdasarkan tingkat kesukaran C1 (Mengingat), C2 (Memahami), C3 (Menerapkan), C4 (Menganalisis), C5 (Mengevaluasi) dan C6 (Menciptakan). Jumlah tes ini adalah 40 soal dalam bentuk pilihan berganda. Sebelum diujikan kepada siswa, tes terlebih dahulu diuji validasi kepada validator dan juga kepada siswa kelas IX SMP di luar siswa sebagai sampel penelitian. Setelah tes selesai di uji coba maka hasilnya yang digunakan tes sebanyak 25 soal untuk penelitian. 
Halaman : $348-354$

Tabel 1. Rekapitulasi Tes Kemampuan Kognitif

\begin{tabular}{|c|c|c|c|c|c|c|c|c|}
\hline No & Indikator & C1 & C2 & C3 & C4 & C5 & C6 & Total \\
\hline 1 & $\begin{array}{l}\text { Menyebutkan macam organ } \\
\text { penyusun sistem peredaran } \\
\text { darah pada manusia. }\end{array}$ & & $\begin{array}{l}1,6 \\
10\end{array}$ & 15 & 9,14 & & & 6 \\
\hline 2 & $\begin{array}{l}\text { Menjelaskan struktur dan fungsi } \\
\text { jantung, pembuluh darah, dan } \\
\text { darah dalam sistem peredaran } \\
\text { darah }\end{array}$ & $\begin{array}{l}3,7,8 \\
11,17\end{array}$ & 18 & $\begin{array}{l}2 \\
12\end{array}$ & 16 & 5 & 19 & 11 \\
\hline 3 & $\begin{array}{l}\text { Menjelaskan mekanisme sistem } \\
\text { peredaran darah pada manusia. }\end{array}$ & $\begin{array}{l}4,13,20, \\
21 \\
23\end{array}$ & & & & 22 & & 6 \\
\hline 4 & $\begin{array}{l}\text { Mendeskripsikan contoh penyakit } \\
\text { yang berhubungan dengan sistem } \\
\text { peredaran darah manusia }\end{array}$ & & & 24 & & & & 2 \\
\hline & TOTAL & 11 & 4 & 4 & 3 & 2 & 1 & 25 \\
\hline
\end{tabular}

Angket digunakan untuk mengambil data tentang analisis sikap pada materi Sistem Peredaran Darah Manusia. Respon yang diharapkan dari subjek adalah menjawab pilihan. Bentuk skala yang digunakan untuk mengukur adalah skala Likert. Skala ini disusun dalam bentuk suatu pernyataan dan diikuti oleh 4 (empat) respon yang menunjukkan tingkatan. Masingmasing pernyataan disediakan pilihan yang

\section{Tabel 2. Rekapitulasi Angket Sikap Siswa}

\begin{tabular}{|c|c|c|c|}
\hline \multirow[t]{2}{*}{ NO } & \multirow[t]{2}{*}{ Indikator } & \multicolumn{2}{|c|}{ Nomor Butir Angket } \\
\hline & & Positif & Negatif \\
\hline 1 & $\begin{array}{l}\text { Menunjukkan rasa syukur kepada Tuhan atas } \\
\text { Ciptaan-Nya yang telah mensejahterakan } \\
\text { kehidupan manusia dengan adanya sistem } \\
\text { peredaran darah manusia }\end{array}$ & $1,3,5$ & 2,4 \\
\hline 2 & $\begin{array}{l}\text { Memiliki rasa ingin tahu pada pembelajaran } \\
\text { sistem peredaran Darah manusia }\end{array}$ & 6,10 & $7,8,9$ \\
\hline 3 & $\begin{array}{l}\text { Menunjukkan ketekunan dan tanggung jawab } \\
\text { dalam belajar dan bekerja baik secara individu } \\
\text { maupun berkelompok pada materi sistem } \\
\text { peredaran darah manusia }\end{array}$ & 11,15 & $12,13,14$ \\
\hline 4 & $\begin{array}{l}\text { Menyampaikan ide, informasi, dan } \\
\text { argumentasi mengenai sistem peredaran } \\
\text { darah manusia }\end{array}$ & $16,17,18$ & 19, 20 . \\
\hline 5 & $\begin{array}{l}\text { Mengajukan pertanyaan mengenai materi } \\
\text { sistem peredaran darah manusia }\end{array}$ & 21, 22, 24 & 23,25 . \\
\hline
\end{tabular}

menjadi alternatif jawaban dan perhitungan skor menggunakan skala linkert dengan ketentuan sebagai berikut.

1. Untuk pernyataan dengan kriteria positif: 4=sangat setuju, 3=setuju, $2=$ tidak setuju, $1=$ sangat tidak setuju.

2. Untuk pernyataan dengan kriteria negatif: 4=sangat tidak setuju , 3=tidak setuju ,2=setuju , 1=sangat setuju. 


\begin{tabular}{clcc}
\hline 6 & $\begin{array}{l}\text { Menghargai pendapat orang lain mengenai } \\
\text { sistem peredaran darah manusia }\end{array}$ & $29,30$. & $26,27,28$. \\
7 & $\begin{array}{l}\text { Partisipasi dalam kelompok belajar pada } \\
\text { materi sistem peredaran darah manusia }\end{array}$ & $32,33$. & $31,34,35$. \\
8 & $\begin{array}{l}\text { Menunjukkan sikap jujur pada pembelajaran } \\
\text { sistem peredaran darah manusia }\end{array}$ & $36,37,38$. & $39,40$. \\
\hline & TOTAL & 20 & 20 \\
\hline
\end{tabular}

Untuk memperoleh data yang dibutuhkan, maka alat pengumpulan data yang digunakan adalah uji validasi, uji reliabilitas, taraf kesukaran soal, dan daya beda soal (Arikunto, 2013). Analisis data dalam penelitian ini menggunakan metode deskriptif kualitatif. Secara deskriptif dimaksudkan untuk memberikan jawaban terhadap rumusan masalah yaitu mengenai hubungan pada materi Sistem Peredaran Darah Manusia.

\section{HASIL PENELITIAN}

\section{Data Tes Kemampuan Kognitif Siswa}

Berdasarkan data yang diperoleh dari hasil penelitian dengan jumlah responden 70 orang terdapat skor tertinggi 92 dan skor terendah 40 (dari kategori skor tes antara rendah sampai tinggi), dengan rata - rata $X=69,65$ dan simpangan baku $(S D)=13,45$. Untuk penafsiran tingkat kecenderungan skor kemampuan kognitif siswa pada materi sistem peredaran darah manusia digunakan harga mean ideal dan simpangan baku ideal (SDi) yang ditunjukkan pada Tabel 4.1 dibawah ini.

Tabel 5. Penafsiran Skor Variabel Kemampuan Kognitif pada Materi Sistem Peredaran Darah Manusia (X)

\begin{tabular}{lccc}
\hline \multicolumn{1}{c}{ Rentangan } & F. Absolut & F. Relatif & Kategori \\
\hline $78,99-$ ke atas & 24 & $34,28 \%$ & Tinggi \\
$66-78,99$ & 15 & $21,42 \%$ & Cukup \\
$53,01-66$ & 23 & $32,85 \%$ & Kurang \\
$53,01-$ ke bawah & 8 & $11,42 \%$ & Rendah \\
\hline
\end{tabular}

Dari tabel diatas diketahui bahwa ada 24 siswa yang memiliki kemampuan kognitif yang tinggi, 15 siswa yang memiliki kemampuan kognitif cukup, 23 siswa yang memiliki kemapuan kognitif yang kurang, dan 8 siswa yang memiliki kemampuan kognitif yang rendah. Berdasarkan hal tersebut diatas maka kemampuan kognitif Siswa SMP Kelas VIII SMP N 7 Binjai Tahun Pembelajaran 2016/2017 cenderung tinggi.

\section{Data Angket Sikap Siswa}

Data sikap siswa diperoleh dari hasil analisis angket sikap siswa yang berjumlah 40 butir. Berdasarkan data yang diperoleh dari hasil penelitian dengan jumlah responden 70 orang terdapat skor tertinggi 95,6 dan skor terendah 62,5 (dari kategori skor angket antara tidak baik sampai baik), dengan rata - rata $X=82,52$ dan simpangan baku $(S D)=6,84$. Untuk penafsiran tingkat kecenderungan skor sikap siswa pada materi sistem peredaran darah digunakan harga mean ideal dan simpangan baku ideal (SDi) yang ditunjukkan pada Tabel 6 dibawah ini. 
Tabel 6. Penafsiran Skor Variabel Sikap Sisa pada Materi Sistem Peredaran Darah Manusia (Y)

\begin{tabular}{lccc}
\hline \multicolumn{1}{c}{ Rentangan } & F. Absolut & F. Relatif & Kategori \\
\hline $87,91-$ ke atas & 15 & $21,42 \%$ & Baik \\
$79,65-87,91$ & 35 & $50 \%$ & Cukup Baik \\
$71,38-79,65$ & 15 & $21,42 \%$ & Kurang Baik \\
$71,38-$ ke bawah & 5 & $7,14 \%$ & Tidak Baik \\
\hline
\end{tabular}

Dari tabel diatas diketahui bahwa ada 15 siswa yang memiliki sikap yang baik, 35 siswa yang memiliki sikap cukup baik , 15 siswa yang memiliki sikap yang kurang baik, dan 5 siswa yang memiliki sikap yang tidak baik. Berdasarkan hal tersebut diatas maka sikap Siswa SMP Kelas VIII SMP N 7 Binjai Tahun Pembelajaran 2016/2017 cenderung cukup baik.

Tabel 7. Uji Normalitas Variabel Penelitian

\begin{tabular}{lccc}
\hline \multicolumn{1}{c}{ Instrumen } & Lhitung & L( $\boldsymbol{\alpha} ; \mathbf{d k})$ & Kesimpulan \\
\hline Kemampuan Kognitif siswa $(\mathrm{X})$ & 0,0982 & 0,1059 & Normal \\
Sikap Siswa $(\mathrm{Y})$ & 0,0976 & & Normal \\
\hline
\end{tabular}

Berdasarkan tabel diatas terlihat $\mathrm{L}_{\text {hitung }}<\mathrm{L}_{\text {tabel }}$ pada taraf signifikan $\alpha=0,05$ sehingga dapat disimpulkan bahwa kedua data terdistribusi normal.

\section{Uji Homogenitas}

Pengujian homogenitas dilakukan dengan Uji Bartlett Dengan $\alpha=0,05$ dari daftar ChiKuadrat dengan $d k-1$ didapat $X_{(0,05,1)}^{2}=3,84$ karena $X_{\text {hitung }}^{2}<X_{\text {tabel }}^{2}$ atau $((1,26<3,84)$ sehingga dapat dinyatakan bahwa data tersebut memiliki varians yang seragam (homogen).

\section{Uji Linieritas dan Keberartian Regresi}

Untuk uji kelinieran dan keberartian regresi $\mathrm{Y}$ atas $\mathrm{X}$ dengan $\mathrm{dk}(1,68)$ pada taraf signifikan $\alpha=0,05$ diperoleh $F_{(0,05 ; 1,68)}=3,134$ sedangkan $F_{\text {hitung }}=16,28$. Dengan demikian diketahui bahwa $F_{\text {hitung }}>F_{(0,05 ; 1,68)}(16,28>3,134$, maka dapat disimpulkan bahwa persamaan regresi $Y$ atas $X$ linier dan berarti pada taraf signifikan $\alpha=$ 0,05 .

\section{Pengujian Koefisien Korelasi Antar Variabel}

Dari hasil analisis korelasi $r_{x y}$ sebesar 0,26, sedangkan $r_{\text {tabel }}$ pada taraf signifikan 0,05 dengan $\mathrm{N}=70$ adalah 0,235 . Dengan demikian $r_{x y}>r_{(0,05 ; 70)}$ atau 0,26>0,235. Berdasarkan pengujian koefisien korelasi yang dilakukan dengan analisa korelasi product moment untuk uji dua pihak. Hipotesis alternatif $(\mathrm{Ha}: \mathrm{p} \neq 0$ ) diterima apabila -1 $\leq r \leq+1 ; r \neq 0$ pada taraf signifikan $\alpha=0,05$. Dari perhitungan koefisien korelasi diatas diperoleh $r=$ 0,26 . Harga $r$ yang diperoleh memenuhi kriteria ($1 \leq 0,26 \leq+1 ; r \neq 0$ ) sehingga dapat disimpulkan bahwa terdapat korelasi yang positif.

\section{Pengujian Besar Sumbangan $X$ dengan $Y$}

Besar sumbangan prediktor kemampuan kognitif siswa dengan kriterium sikap siswa adalah $0,07 \times 100 \%=7 \%$. Sedangkan sisanya berasal dari faktor lain misalnya faktor lingkungan belajar, faktor ekonomi, orang tua, dan yang lain - lain, dimana pada penelitian ini tidak diteliti.

\section{Uji Hipotesis (uji t)}

Dari hasil uji hipotesis diperoleh harga $t_{\text {hitung }}=2,434$ sedangkan dari daftar distribusi dengan $\mathrm{dk}=68$ pada taraf $\alpha=0,05$ diperoleh $t_{(0,05 ; 68)}=1,97$. Kriteria pengujian $\mathrm{Ha}$ adalah diterima apabila $t_{\text {hitung }}>t_{\text {tabel }}$ dan ditolak jika $\mathrm{Ha}$ sebaliknya. Karena harga $t_{\text {hitung }}>t_{(0,05 ; 68)}=(2,434>$ 1,97), dengan demikian maka $\mathrm{Ha}$ diterima sekaligus menolak Ho sehingga dapat disimpulkan ada pengaruh signifikan antara kemampuan kognitif dengan sikap siswa kelas VIII di SMP Negeri 7 Binjai Tahun Pembelajaran 2016/2017.

\section{PEMBAHASAN}

Dari hasil penelitian diperoleh rata-rata kemampuan kognitif siswa adalah 69,65 dari skor maksimal 92. Siswa dalam kategori tinggi sebanyak 24 orang (34\%) dalam kategori cukup 15 orang (21\%) dalam kategori kurang 23 orang (32\%) dan dalam kategori rendah 8 orang (11\%). Hal ini berarti kemampuan kognitif siswa kelas VIII SMP Negeri 7 Binjai Tahun Pembelajaran 2016/2017 tergolong tinggi dan dapat dikatakan bahwa siswa tersebut sudah memiliki kemampuan kognitif yang tinggi pada materi sistem peredaran darah manusia. Dalam penelitian Sikap siswa diperoleh 
rata- rata 79,65 dengan skor maksimal 95,6, dalam kategori baik sebanyak 15 orang (21\%), dalam kategori cukup baik 35 orang (50\%), dalam kategori kurang baik 15 orang (21\%) dalam kategori tidak baik 5 orang (7\%), hal itu menunjukkan bahwa siswa dan siswi SMP N 7 Binjai memiliki sikap yang cenderung cukup baik. Dari hasil penelitian ini rata - rata hasil angket sikap siswa 69,65 dan kemampuan kognitif memberikan konstribusi sebesar $7 \%$ dalam peningkatan hasil belajar siswa.

Dari hasi analisis data diperoleh bahwa antara kemampuan kognitif dengan sikap siswa di kelas VIII SMP N 7 Binjai Tahun Pembelajaran 2016/2017 berhubungan secara linier, hubungan ini dilihat dari pengujian hipotesis, dengan penerimaan hipotesis alternatif. Selanjutnya, setelah uji kelinieran regresi diketahui untuk melihat apakah hubungan kemampuan kognitif dengan sikap siswa berarti dilakukan uji keberartian regresi, penerimaan hipotesis alternatif $(\mathrm{Ha} ; \mathrm{\rho}=0)$ ini diartikan dari persamaan $\hat{\mathrm{Y}}$ $=73,31+0,12 \times$ menunjukkan adanya korelasi positif, artinya ada hubungan antara kedua variabel yang dikorelasikan dari persamaan regresi linier tersebut menunjukkan berarti. Dari perhitungan koefisien korelasi diperoleh $r=$ 0,2598410 . Harga $r$ yang diperoleh memenuhi kriteria $(-1 \leq 0,2598410 \leq+1 ; r \neq 0)$ sehingga dapat disimpulkan bahwa terdapat korelasi yang positif antara kemampuan kognitif siswa pada materi Sistem Peredaran Darah Manusia (X) dengan Sikap siswa pada materi Sistem Peredaran Darah Manusia (Y). Korelasi yang didapat termasuk ke dalam kategori rendah, hal ini juga dijelaskan dalam penelitian ilmiah Yayat (2009): "Sikap dapat ditumbuhkan dan dikembangkan melalui proses belajar. Dalam proses belajar tidak terlepas dari proses komunikasi dimana terjadi proses transfer pengetahuan dan nilai. Jika sikap merupakan hasil belajar, maka kunci utama belajar sikap terletak pada proses kognisi dalam belajar siswa. Dalam penelitian ini dapat dilihat bahwa terdapat hubungan yang signifikan dan berarti antara kemampuan kognitif siswa dengan sikap siswa, hal ini juga sesuai dengan penelitian yang telah dilakukan Mirna (2013) di SMA Negeri 5 Banda Aceh mengenai pengetahuan dan sikap di dapatkan kesimpulan bahwa ada hubungan yang sigfnfikan antara pengetahuan dan sikap siswa, hasil penelitian ditunjukkan oleh nilai $p$-value 0,021 . Berdasarkan hasil penelitian siswa yang memiliki kognitif tinggi juga memiliki sikap yang baik, namun dalam penelitian ini juga didapatkan penemuan baru yaitu bahwasanya siswa yang memiliki kognitif rendah nyatanya memiliki sikap yang baik, dan siswa yang memiliki kognitif tinggi ternyata sikapnya tidak baik, hal ini dikarenakan beberapa faktor yang ada pada individu masing masing seperti adanya perbedaan dalam bakat, minat, pengalaman, pengetahuan, intensitas dan juga situasi lingkungan (Yayat, 2009).

Hal tersebut sesuai Menurut Bloom, serendah apapun tingkatan proses kognisi siswa dapat mempengaruhi sikap. Namun demikian, tingkatan kognisi yang rendah mungkin saja dapat mempengaruhi sikap, tetapi sangat lemah pengaruhnya dan sikap cenderung labil", Proses kognisi yang dapat menumbuhkan dan mengembangkan sikap secara signifikan, sejalan dengan taksonomi Bloom, adalah pada taraf analisis, sintesis, dan evaluasi. Menurut Notoatmodjo (2003), pengetahuan atau kognitif merupakan domain yang sangat penting untuk terbentuknya tindakan seseorang (Over behaviour). Menurut Notoadmodjo (2010) Pengetahuan manusia akan mempengaruhi perilaku manusia. Dalam menentukan sikap yang utuh (total attitude) pengetahuan, pikiran, emosi, dan keyakinan memegang peranan penting, pengetahuan yang dimiliki seseorang akan menimbulkan kesadaran, dan akhirnya akan menyebabkan orang berprilaku sesuai dengan pengetahuan yang dimilikinya. Baron dalam Maolinda et al, (2012), menyatakan bahwa pengetahuan juga merupakan faktor kekuatan terjadinya perubahan sikap.

\section{KESIMPULAN}

Hasil penelitian menunjukkan bahwa terdapat hubungan yang signifikan antara kemampuan kognitif dengan sikap siswa di kelas VIII SMP Negeri 7 Binjai Tahun Pembelajaran 2016/2017 pada materi sistem peredaran darah manusia dengan kontribusi kemampuan kognitif terhadap sikap sebesar $7 \%$.

\section{UCAPAN TERIMA KASIH}

Terima kasih kepada Ibu Dra. Hj. Merry Yosepha Gusnaini selaku Kepala Sekolah SMP Negeri 7 Binjai yang telah banyak membantu selama penelitian berlangsung.

\section{DAFTAR PUSTAKA}

Arikunto, S. 2012. Dasar-dasar Evaluasi Pendidikan. Jakarta: Bumi Aksara.

Arikunto, S. 2013. Prosedur Penelitian Suatu Pendekatan Praktik. Jakarta Penerbit Rineka Cipta. 
Ariyani, D. 2013. Penerapan Pembelajaran Materi Sistem Peredaran Darah Dengan Metode Simulasi Taman Sirkulasi Berbasis Bioedutainment di SMP Negeri 1 Gabus Kabupaten Pati (Skripsi). Semarang : FMIPA UNNES.

Ayu, Mirna. 2013. Hubungan Pengetahuan dan Sikap Dengan Perilaku Kesehatan Reproduksi pada Remaja Putri Di SMA 5 Banda Aceh.(Jurnal Karya Tulis Ilmiah). Banda Aceh: STIKES U'budiyah.

Daryanto, H. 2008. Evaluasi Pendidikan. Jakarta: Rineka Cipta.

Ercahaya, Novita. 2016. Analisis Pengetahuan dan Sikap Siswa pada Materi Jamur di Kelas $X$ Semester I SMA Negeri 1 Tarutung (Skripsi). Medan : FMIPA Unimed.

Huda I. 2010. Penerapan Pendekatan JAS dengan Metode Role Playing pada Materi Sistem Peredaran Darah di SMP 10 Semarang (Skripsi). Semarang: FMIPA UNNES.

Indra, Tri. 2012. Meningkatkan Keterampilan Menyusun Instrumen Hasil Belajar Berbasis Modul Interaktif Bagi Guru-Guru Ipa SmpN Kota Magelang. Journal of Educational Research and Evaluation $1: 2$.

Kurniawan Samsul. 2013. Pendidikan Karakter Konsepsi dan Implementasinya Secara Terpadu di Lingkungan Keluarga, Sekolah, Perguruan Tinggi, dan Masyarakat. Yogyakarta: Ar-Ruzz Media.

Milfayetty, S. 2015. Psikologi Pendidikan. Medan: UNIMED.

Mira S, dkk. 2016. Analisis Pengetahuan dan Ketuntasan Siswa pada Materi Bioteknologi di SMA Negeri Se-Kota Binjai. Jurnal Pendidikan Biologi 5:(3):180186.

Munawar, dan Z Abidin. 2014. Hubungan Antara Pengetahuan Alam dan Lingkungan Hidup Dengan Perilaku Siswa dalam Pengelolaan Kebersihan Lingkungan Sekolah di SMAN 15 Adidarma Banda Aceh. Serambi Saintia 2(2):134-142.

Notoatmodjo, S. 2003. Pendidikan dan Perilaku Kesehatan. Jakarta: PT Rineka Cipta.

Notoatmodjo, S. 2010. Ilmu Perilaku Kesehatan. Jakarta: PT Rineka Cipta.
Purwanto, dan Arinto, 2015. Eksplorasi Ilmu Alam Untuk Kelas VIII SMP dan MTs. Solo: PT Tiga Serangkai Pustaka Mandiri.

Purwanto. 2016. Implementasi Penilaian Sikap Berdasarkan Kurikulum 2013 pada Pembelajaran Bahasa Indonesia Untuk Membentuk Karakter Siswa di Sekolah Menengah Pertama Surakarta (Naskah Publikasi/Thesis. Surakarta: Program Studi Magister Pengkajian Bahasa Sekolah Pascasarjana Universitas Muhammadiyah Surakarta.

Rusyna, A. 2014. Keterampilan Berpikir. Yogyakarta. Ombak.

Salmiah, 2015. Kompetensi Guru Madrasah Ibtidaiyah Mendesain Penilaian Sikap Dalam Pembelajaran Sesuai Kurikulum 2013, (http://bdkaceh.kemenag.go.id, diakses tanggal 20 Desember 2016).

Sinaga, dan M Silitonga. 2011. Anatomi Fisiologi Tubuh Manusia. Medan: UNIMED

Sudjana. 2005. Metoda Statistik. Bandung: Tarsito.

Sudjana. 2009. Penilaian Hasil Proses Belajar Mengajar. Bandung: Remaja Rosdakarya.

Sugiyono. 2015. Metode Penelitian Pendidikan. Bandung: CV Alfabeta.

Suhardiyanto A. 2009. Peningkatan Kualitas Pendidikan Melalui Model Pembelajaran Kooperatif Berbasis Konstruktivistik. Jurnal Lembaran Ilmu Kependidikan 38(1): 68-77.

Suharyat, Y. 2009. Hubungan antara Sikap, Minat dan Perilaku Manusia. e- Journal Unisma. 1(1): 1-17. 